\title{
Effects of organic and inorganic phosphorus sources on nitrogen fixation by field grown common bean on an Alfisol and an Ultisol in Kakamega, Kenya
}

\author{
Francis Ajebesone NGOME \\ INRES, University of Bonn, Germany, Karlrobert Kreiten 13, 53115, Bonn, Germany \\ E-mail:ngomajebe@yahoo.com
}

\begin{abstract}
A field study was carried out in 2005 in Kakamega to quantify the effects of organic and inorganic sources of phosphorus on nitrogen fixation of common bean by the ${ }^{15} \mathrm{~N}$ Natural Abundance method. Field experiments were conducted on two different soil groups (Alfisol and Ultisol) in 20 farmers' fields. Six treatments: control with no input, inorganic phosphorus, inorganic nitrogen, inorganic phosphorus plus nitrogen, seed priming with phosphorus and farmyard manure. These treatments were replicated three times in a randomized complete block design. Maize was used as a non-fixing reference plant for ${ }^{15} \mathrm{~N}$ analysis. The results showed that the total nitrogen accumulation by common bean ranged from 5 to $20 \mathrm{~kg} \mathrm{ha}^{-1}$ in the Alfisol and from 8 to $26 \mathrm{~kg} \mathrm{ha}^{-1}$ in the Ultisol and treatments in the Ultisol accumulated $20 \%$ more biomass compared to treatments in the Alfisol. Further, the rate of nitrogen fixation was $50 \%$ to $54 \%$ Ndfa for the inorganic phosphorus sources and $40 \%$ to $51 \%$ Ndfa for the organic phosphorus source. Seed priming with phosphorus, inorganic nitrogen and the control obtained less than $40 \%$ Ndfa for nitrogen fixation. These results illustrate that phosphorus sources could differentially enhance nitrogen fixation by common bean in different soil groups in smallholder farming systems in Kakamega.

() 2009 International Formulae Group. All rights reserved.
\end{abstract}

Keywords: Legume, ${ }^{15} \mathrm{NNAM}, \mathrm{N}_{2}$ fixation, Phaseolus vulgaris L., smallholder farmers.

\section{INTRODUCTION}

The common bean (Phaseolus vulgaris L.) is the most widely cultivated grain legume in Western Kenya. It is cultivated in association with maize (Shepherd and Soule, 1998), and constitutes one of the major sources of protein for the local population. Additionally, the common bean can fix nitrogen, which can potentially add nitrogen (N) to the soil $\mathrm{N}$ pool (Larnier et al., 2005) and hence restore soil fertility, especially in smallholder farming systems. However, a number of factors influence the rate of $\mathrm{N}_{2}$ fixation by legumes, particularly nutrient deficiency (Giller, 2001; Ngome, 2006).

Several of the nutrients essential for growth of common bean play specific roles in nodulation and nitrogen fixation. Deficiency in one or more of these nutrients can cause acute reduction in the number and size of nodules formed, and in the amount of $\mathrm{N}_{2}$ fixed (Adjei et al., 2002; O'Hara, 2001). Phosphorus $(\mathrm{P})$ is essential to maximize and sustain high crop yield potential in continuous cultivation systems (Kuang et al., 2005) and P deficiency in legumes could seriously reduce nitrogen fixation (Hogh-Jensen et al., 2002). Ojiem (2006) noted an increase in biomass accumulation and nodulation performance of common bean (var. KK8) by $50 \%$ with application of $30 \mathrm{~kg} \mathrm{P} \mathrm{ha}^{-1}$ and concluded that application of $\mathrm{P}$ is essential for $\mathrm{N}_{2}$ fixation by common bean. Kuang et al. (2005) and Mapfumo et al. (2005) also observed an increase in nodulation and \% Ndfa with application of P. Similarly, Somado et al. (2003) reported a three- to eight-fold increase in the amount of $\mathrm{N}$ accumulation from $\mathrm{N}_{2}$ 
fixation after $\mathrm{P}$ application. Moreover, when field-grown common bean that depends on $\mathrm{N}_{2}$ fixation receives an inadequate supply of $\mathrm{P}$, it may show signs of $\mathrm{N}$ deficiency (Marschner, 1995). Conversely, high levels of nitrogen have been reported to reduce nitrogen fixation. Wanek and Arndt (2002) observed a reduction in soybean root nodules and a decline in nitrogen fixation from $84 \%$ to $3 \%$ Ndfa with an increase in nitrate concentration from 0.25 to $25 \mathrm{mM}$. But, the Alfisol and Ultisol of Kakamega have low level of nitrogen (Ngome, 2006). Hence, in addition to phosphorus application small quantities of nitrogen ("starter-N") could be applied to stimulate legume growth and establishment between root emergence and the onset of active $\mathrm{N}_{2}$ fixation (Giller and Cadisch, 1995).

Sources of phosphorus available to smallholder farmers include inorganic or mineral $\mathrm{P}$, and organic $\mathrm{P}$ sources like animal manure, compost and green manure (Ojiem, 2006). While inorganic $P$ increases only soil available $\mathrm{P}$ level, organic $\mathrm{P}$ sources like farm yard manure (FYM) can additionally ameliorate soil physical, chemical and biological properties when applied regularly in crop lands (Ngome, 2006). Seed priming with $\mathrm{P}$ could be another source of $\mathrm{P}$ available to crops particularly for resource poor farmers (Musa et al., 2001). It involves soaking of seeds in $\mathrm{P}$ nutrient solution before seeding, which could make $P$ available to the plant and hence enhance crop growth and nitrogen fixation (Harris et al., 2005).

Several methods exist to quantify nitrogen fixation. However, the amount of nitrogen fixed will depend on the kind of legume, the environmental conditions and the non-fixing reference crop used (Giller, 2001). The Nitrogen-15 Natural Abundance Method ( $\left.{ }^{15} \mathrm{NNAM}\right)$ is frequently used to estimate nitrogen fixation by field grown legumes although the choice of the non-fixing reference plant could be crucial (Gathumbi et al., 2002). The use of different reference plants could influence the rate of nitrogen fixed by a legume. Gehring and Vlek (2004) observed variations of nitrogen fixation with reference plants and concluded that nonnitrogen-fixing legumes could be better reference plants compared to non-legumes due to their taxonomic proximity to nitrogenfixing legumes. However, maize, a non- legume has been widely used as a reference plant in estimating nitrogen fixation in field grown legumes (Chikowo et al., 2004; Gathumbi et al., 2002; Giller and Wilson, 1991). The non-fixing reference plant is expected to have lower nitrogen content and higher ${ }^{15} \mathrm{~N}$ value because it has only one nitrogen source compared to the nitrogen fixing legume, which obtains nitrogen from the atmosphere and from the soil (Chikowo et al., 2004).

Most of the soils in western Kenya are highly depleted, with widespread nutrient deficiencies, particularly $\mathrm{N}$ and $\mathrm{P}$ (Nambiro, 2008). It is assumed that the application of small quantities of $\mathrm{P}$ in the organic or inorganic form to field grown common bean could improve the performance of the crop in fixing $\mathrm{N}_{2}$, which could be beneficial to the associated maize crop. Although it is already known that $\mathrm{P}$ availability is necessary for $\mathrm{N}_{2}$ fixation by legumes, no information is available on the extent to which addition of different $\mathrm{P}$ sources can increase the capacity of common bean to fix $\mathrm{N}_{2}$ in different soil groups in smallholder farming systems. Thus, the objective of this study was to investigate the effect of organic and inorganic $\mathrm{P}$ sources on $\mathrm{N}_{2}$ fixation of field grown common bean on an Alfisol and an Ultisol in Kakamega, Kenya.

\section{MATERIALS AND METHODS \\ Experimental site}

The study was carried out in Kakamega District (Kenya), located at $34^{\circ} 20^{\prime}$ and $35^{\circ} \mathrm{E}$ and $0^{\circ} 15^{\prime}$ and $1^{\circ} \mathrm{N}$; with altitude varying from $1250 \mathrm{~m}$ to 2000 masl. The annual rainfall ranges between $1200-2100$ $\mathrm{mm}$, and annual mean temperatures vary between 18 to $21^{\circ} \mathrm{C}$. Field experiments were conducted during the short rainy season (August to November 2005) on two soil groups: sandy Alfisol in the North and clayey Ultisol in the South of the district (Soil Survey Staff, 1992). Some chemical characteristics of the Alfisol and the Ultisol adapted from Ngome (2006) are illustrated in Table 1.

\section{Experimental design and treatment application}

Experiments were set up in all the fields between the $1^{\text {st }}$ and $10^{\text {th }}$ of August 2005. The experimental design was a randomized 
Table 1: Mean values for some soil chemical characteristics of an Alfisol and an Ultisol in Kakamega, Kenya.

\begin{tabular}{|c|c|c|}
\hline \multirow{2}{*}{ Soil characteristics } & \multicolumn{2}{|c|}{ Soil group } \\
\hline & Alfisol & Ultisol \\
\hline $\mathrm{pH}$ & $4.59 \pm 0.29$ & $4.56 \pm 0.38$ \\
\hline $\mathrm{C}$ org $(\%)$ & $1.98 \pm 0.71$ & $5.71 \pm 0.77$ \\
\hline Total N (\%) & $0.12 \pm 0.03$ & $0.25 \pm 0.05$ \\
\hline $\mathrm{C} / \mathrm{N}$ ratio & $17.00 \pm 4.37$ & $23.60 \pm 2.98$ \\
\hline Available $\mathrm{P}\left(\mathrm{mg} \mathrm{kg}^{-1}\right)$ & $7.23 \pm 3.12$ & $5.24 \pm 2.77$ \\
\hline Extractable $\mathrm{K}\left(\mathrm{g} \mathrm{kg}^{-1}\right)$ & $0.10 \pm 0.04$ & $0.24 \pm 0.09$ \\
\hline Extractable $\mathrm{Ca}\left(\mathrm{g} \mathrm{kg}^{-1}\right)$ & $0.58 \pm 0.21$ & $1.88 \pm 0.39$ \\
\hline Extractable $\mathrm{Mg}\left(\mathrm{g} \mathrm{kg}^{1}\right)$ & $0.06 \pm 0.02$ & $0.02 \pm 0.07$ \\
\hline \multicolumn{3}{|c|}{$\begin{array}{l}\text { pH: } 2 \mathrm{NKCl}, \mathrm{C} \text { org: CHN-Analyzer, Total N: Kjehldahl } \\
\text { Available, P: Modified Olsen Extractable, K: Calcium- } \\
\text { acetate-lactate extract Extractable, Ca: Ammonium } \\
\text { acetate extract Extractable, Mg: Calcium chloride extracts } \\
\text { (VD LUFA) } \pm \text { indicates standard deviation from the mean } \\
\text { Source: Ngome (2006). }\end{array}$} \\
\hline
\end{tabular}

complete block with six treatments replicated three times. The plant material was the common bean variety KK 8 and the maize hybrid HB 513, was used as the reference crop for the ${ }^{15} \mathrm{~N}$ analysis. The common bean and maize seeds were obtained from the Kenya Agricultural Research Institute (KARI) in Kakamega. The treatment plots were $4.5 \times 4.0$ $\mathrm{m}$ in size and were separated by a distance of $0.5 \mathrm{~m}$. Meanwhile, a distance of $1.0 \mathrm{~m}$ was used to separate the blocks. The common bean was planted with a spacing of $75 \times 20 \mathrm{~cm}$. Maize was intercropped between rows of common bean at $25 \mathrm{~cm}$ between plants in the same row. Two seeds of common bean or maize were planted per hole, but were thinned to one plant per hill three weeks after crop emergence. The treatments included the following:

(i) Control: No external inputs.

(ii) Mineral P: Inorganic P fertilizer applied at a rate of $15 \mathrm{~kg} \mathrm{P}^{-1}$ from Triple super phosphate (20\% P).

(iii) Mineral N: Inorganic $\mathrm{N}$ fertilizer applied at a rate of $11.5 \mathrm{~kg} \mathrm{~N} \mathrm{ha}^{-1}$ from Urea $(46 \% \mathrm{~N})$. (iv) Mineral $\mathrm{P}+\mathrm{N}$ : Inorganic $\mathrm{P}$ and $\mathrm{N}$ fertilizers applied at a rate of $15 \mathrm{~kg} \mathrm{Pha}^{-1}$ and
$11.5 \mathrm{~kg} \mathrm{~N} \mathrm{ha}^{-1}$ respectively from the same above mentioned sources.

(v) Seed priming with P: This treatment consisted of soaking common bean seeds in $\mathrm{P}$ nutrient solution $(100 \mathrm{mM} \mathrm{P})$ for 24 hours prior to sowing. The nutrient solution was produced by adding $13.6 \mathrm{~g}$ of $\mathrm{K}_{2} \mathrm{HPO}_{4}$ per liter of distilled water.

(vi) Farmyard manure (FYM): Well decomposed FYM $\left(116 \mathrm{~g} \mathrm{C} \mathrm{kg}^{-1}, 12 \mathrm{~g} \mathrm{~N} \mathrm{~kg}^{-1}\right.$ and $0.5 \mathrm{~g} \mathrm{P} \mathrm{kg}^{-1}$ obtained from KARI Kakamega) was applied at $2.5 \mathrm{Mg} \mathrm{ha}^{-1}$ as organic P source.

The mineral $\mathrm{P}$ and the FYM were applied at planting. The mineral $\mathrm{N}$ was topdressed one month after crop emergence in a circular mode around the stems of the plants. All plots were kept weed-free throughout the experiment. No inoculants, fungicides or pesticides were used.

\section{Sample preparations}

Plants were sampled for biomass accumulation 80 days after planting. The above-ground biomass for the common bean was determined by randomly selecting five plants per plot in the middle rows. Five neighboring maize plants were also selected to serve as non-fixing reference plants in the ${ }^{15} \mathrm{~N}$ analysis. The plants were all cut above-ground level, washed, air dried, chopped and mixed, and a representative sub-sample of $100 \mathrm{~g}$ was weighed using a precision weighing scale (Toledo PL602-S) with a $0.001 \mathrm{~g}$ precision. These sub-samples were oven-dried at $70{ }^{\circ} \mathrm{C}$ for 48 hours to a constant weight. The dried sub-samples were finely ground using a micro impact-grinding mill (IKA MF10 B) with a 1 $\mathrm{mm}$ sieve for grinding, and sealed in labeled plastic bags for eventual analyses.

\section{Sample analysis and calculations}

Five milligrams from each ground plant sample was analyzed for $\% \mathrm{~N}$ and $\%{ }^{15} \mathrm{~N}$ with an ANCA mass spectrometer (SL 20-20, PDZ Europa). Maize was used as the nonfixing reference plant. B-value (natural discrimination of the heavy ${ }^{15} \mathrm{~N}$ isotope by the nitrogenase enzyme complex) for common bean obtained from Ngome (2006) was 2.8\%o. The natural abundance of the stable isotope ${ }^{15} \mathrm{~N}$ in the samples $\left(\delta{ }^{15} \mathrm{~N}\right)$ was determined as shown in equation (1) and the percentage of nitrogen derived from the atmosphere 
(\%Ndfa) was estimated by the ${ }^{15} \mathrm{~N}$ natural abundance method $\left({ }^{15} \mathrm{NNAM}\right)$ according to equation (2) (Gathumbi et al., 2002):

i. Nitrogène from $\mathrm{N}_{2}$ fixation $(\%)=$

$$
\left(\frac{\delta^{15} \mathrm{~N}_{\text {maize }}-\delta^{15} \mathrm{~N}_{\text {beant }}}{\delta^{15} \mathrm{~N}_{\text {maize }}-\mathrm{B}}\right) \times 10 \mathrm{C}(1)
$$

Where B represents the $\delta^{15} \mathrm{~N}$ of the same $\mathrm{N}$-fixing plant grown in the $\mathrm{N}$-free medium

ii.

$$
\delta^{15} \mathrm{~N}(\% \circ)=\left(\frac{\mathrm{R}_{\text {sample }}}{\mathrm{R}_{\text {standard }}}-1\right) \times 1000 \text { (2) }
$$

where $R_{\text {standard }}$ and $R_{\text {sample }}$ were the respective ratios of ${ }^{15} \mathrm{~N} /{ }^{14} \mathrm{~N}$ atoms in the atmosphere $(0.3663 \%$ o $)$ and the sample. By definition the $\delta^{15} \mathrm{~N}$ of atmospheric $\mathrm{N}_{2}$ is zero. B is ${ }^{15} \mathrm{~N}$ discrimination.

Percentage of nitrogen obtained from the soil (\%Ndfs) was obtained by subtracting $\%$ Ndfa from $100 \%$. The amount of $\mathrm{N}$ accumulated from $\mathrm{N}_{2}$ fixation (BNF-N or NNdfa) was obtained by multiplying $\%$ Ndfa $\mathrm{x}$ $\% \mathrm{~N} x$ above ground biomass of the common bean, $\mathrm{N}$ accumulation from the soil (N-Ndfs) was calculated by multiplying $\% \mathrm{Ndfs} x \% \mathrm{~N} x$ above ground biomass, and total $\mathrm{N}$ accumulation (N-total) was calculated by adding N-Ndfa + N-Ndfs.

The $\mathrm{P}$ uptake by common bean $(\% \mathrm{P}$ uptake) were measured colorimetrically with an auto-analyzer (Eppendorf Ecom 6122) after dry-ashing ( 4 hours at $500{ }^{\circ} \mathrm{C}$ followed by 3 hours at $450{ }^{\circ} \mathrm{C}$ after ash dissolution in saturated $\mathrm{NH}_{4} \mathrm{NO}_{3}$-solution) finely ground sub-samples and extraction with $6 \mathrm{M} \mathrm{HCl}$. The analyses were carried out in the Institute of Crop Science and Resource Conservation at the University of Bonn, Germany.

\section{Data analysis}

Data collected on above-ground biomass accumulation, $\% \mathrm{~N}, \delta^{15} \mathrm{~N}, \mathrm{~N}-\mathrm{Ndfa}, \mathrm{N}$ Ndfs, N-total, \%P uptake by common bean were analyzed for their variance (ANOVA) using SPSS version 14.0 for Windows (SPSS, 2005). Where significant differences were detected, comparisons of means were done using the Turkey Test at 5\% significant level.

\section{RESULTS}

The above ground biomass accumulation of the common bean varied significantly $(\mathrm{P}<0.05)$ with soil groups and treatment applications. Generally, treatments laid out in the Ultisol accumulated about $20 \%$ more biomass compared to those laid out in the Alfisol (Table 3). In the Alfisol, the organic phosphorus source (FYM) accumulated $0.75 \mathrm{Mg} \mathrm{ha}{ }^{-1}$, the inorganic phosphorus sources registered 0.55 to 0.65 $\mathrm{Mg} \mathrm{ha}^{-1}$, seed priming with $\mathrm{P}$ had $0.6 \mathrm{Mg} \mathrm{ha}^{-1}$ and inorganic nitrogen accumulated $0.62 \mathrm{Mg}$ $\mathrm{ha}^{-1}$. The lowest biomass accumulation of 0.22 $\mathrm{Mg} \mathrm{ha}{ }^{-1}$ was observed with the control treatment (Table 3). In the Ultisol, The inorganic $\mathrm{P}+\mathrm{N}$ accumulated the highest biomass of $0.87 \mathrm{Mg} \mathrm{ha}^{-1}$ while the control treatment accumulated the lowest biomass of $0.30 \mathrm{Mg} \mathrm{ha}^{-1}$ (Table 3). Organic phosphorus, inorganic nitrogen and seed priming with $\mathrm{P}$ accumulated $0.79,0.82$ and $0.56 \mathrm{Mg} \mathrm{ha}^{-1}$ of biomass, respectively (Table 3 ).

The delta-15-N $\left(\delta^{15} \mathrm{~N}\right)$ values for common bean in all the treatments were constantly lower than those of the corresponding reference maize plants (Table 2 ). Generally, higher values of delta-15-N were observed in the Ultisol compared to the Alfisol for all the treatments. In both the Alfisol and the Ultisol, the delta- $15-\mathrm{N}$ values for common bean and maize were lower for the inorganic phosphorus sources compared to the organic phosphorus source and seed priming with $\mathrm{P}$. However, no significant differences $(\mathrm{P}<0.05)$ were observed between the treatments for delta-15- $\mathrm{N}$ in common bean or maize (Table 2).

Similarly, the percentage of nitrogen in the shoot of the common bean was higher for treatments laid out in the Ultisol compared to those laid in the Alfisol (Table 3). As expected, $\% \mathrm{~N}$ was higher for the inorganic $\mathrm{P}+\mathrm{N}$ and inorganic $\mathrm{N}$ treatments in both the Alfisol and the Ultisol. But no significant differences $(\mathrm{P}<0.05)$ were observed among the treatments for this parameter (Table 3 ).

The percentage of nitrogen obtained from the atmosphere estimated using ${ }^{15}$ NNAM with maize as non-fixing reference plant varied widely among treatments application, although no significant differences $(\mathrm{P}<0.05)$ were observed (Table 3$)$. Treatments laid out in the Alfisol had a higher $\%$ Ndfa of $35 \%$ to $55 \%$ compared to those laid in the Ultisol which registered $31 \%$ to $50 \%$ Ndfa (Table 3). 
Table 2: Effect of treatments on Delta-15-N $\left(\delta^{15} \mathrm{~N}\right)$ mean values for common bean and maize and phosphorus uptake by common bean in an Alfisol and an Ultisol in Kakamega, Kenya.

\begin{tabular}{lcccccc}
\hline & \multicolumn{7}{c}{ Soil group } \\
\cline { 2 - 6 } Treatment & \multicolumn{7}{c}{ Alfisol } & \multicolumn{3}{c}{ Ultisol } \\
\cline { 2 - 6 } & $\begin{array}{c}\text { \%P } \\
\text { Bean }\end{array}$ & $\begin{array}{c}\boldsymbol{\delta}^{\mathbf{1 5}} \mathbf{N} \\
\text { Bean }^{*}\end{array}$ & $\boldsymbol{\delta}^{\mathbf{1 5}} \mathbf{N}$ Maize & $\begin{array}{c}\mathbf{\%} \mathbf{P} \\
\text { Bean }\end{array}$ & $\boldsymbol{\delta}^{\mathbf{1 5}} \mathbf{N}$ Bean & $\boldsymbol{\delta}^{\mathbf{1 5}} \mathbf{N}$ Maize \\
\hline Mineral P+N & 0.34 & 2.06 & 4.40 & 0.36 & 2.82 & 5.18 \\
P-Primed & 0.34 & 3.53 & 5.89 & 0.33 & 3.66 & 6.20 \\
FYM & 0.34 & 3.32 & 6.23 & 0.34 & 3.42 & 5.69 \\
Mineral N & 0.31 & 2.61 & 4.09 & 0.29 & 3.54 & 4.93 \\
Mineral P & 0.35 & 2.69 & 5.81 & 0.37 & 3.01 & 5.79 \\
Control & 0.30 & 2.77 & 4.44 & 0.29 & 3.24 & 5.01 \\
SD & 0.05 & 1.83 & 1.84 & 0.07 & 1.81 & 1.49 \\
Significance & $\mathrm{ns}$ & $\mathrm{ns}$ & $\mathrm{ns}$ & $\mathrm{ns}$ & $\mathrm{ns}$ & $\mathrm{ns}$ \\
(5\%) & & & & & & \\
\hline
\end{tabular}

Values are means of 10 replicates in each soil type. ns: non-significant difference. SD: standard deviation.

Table 3: Effect of treatments on biomass production, nitrogen fixation and nitrogen accumulation by common bean in an Alfisol and an Ultisol of Kakamega, Kenya.

\section{Soil group}

\begin{tabular}{|c|c|c|c|c|c|c|c|c|c|c|c|}
\hline \multicolumn{6}{|c|}{ Alfisol } & \multicolumn{6}{|c|}{ Ultisol } \\
\hline 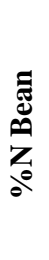 & 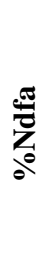 & $\frac{\mathscr{n}}{z_{0}^{\circ}}$ & 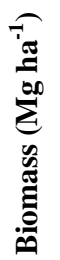 & 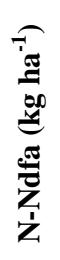 & 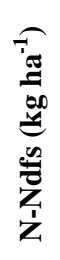 & 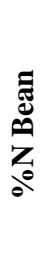 & 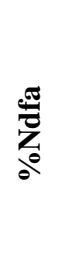 & $\begin{array}{l}\stackrel{n}{E} \\
z_{0}^{\circ}\end{array}$ & 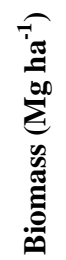 & 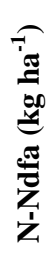 & 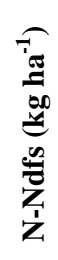 \\
\hline
\end{tabular}

\begin{tabular}{lccccccccccccc} 
Treatment & & & & & & & & & & & & \\
\hline $\begin{array}{l}\text { Mineral } \\
\text { P+N }\end{array}$ & 2.70 & 54.43 & 45.57 & $0.65 \mathrm{ab}$ & $7.51 \mathrm{a}$ & 8.78 & 2.94 & 47.42 & 52.58 & $0.87 \mathrm{a}$ & $12.22 \mathrm{a}$ & 13.90 \\
P-Primed & 2.65 & 40.03 & 59.97 & $0.60 \mathrm{ab}$ & $5.14 \mathrm{ab}$ & 9.91 & 2.76 & 38.78 & 61.22 & $0.56 \mathrm{ab}$ & $6.70 \mathrm{ab}$ & 8.83 \\
FYM & 2.67 & 51.46 & 48.54 & $0.75 \mathrm{a}$ & $7.97 \mathrm{a}$ & 12.39 & 2.78 & 39.76 & 60.24 & $0.79 \mathrm{ab}$ & $7.47 \mathrm{ab}$ & 13.48 \\
Mineral N & 2.68 & 38.17 & 61.83 & $0.62 \mathrm{ab}$ & $4.76 \mathrm{ab}$ & 11.76 & 2.82 & 31.39 & 68.61 & $0.82 \mathrm{a}$ & $7.17 \mathrm{ab}$ & 15.87 \\
Mineral P & 2.64 & 54.76 & 45.24 & $0.55 \mathrm{ab}$ & $6.91 \mathrm{ab}$ & 6.93 & 2.71 & 50.34 & 49.66 & $0.71 \mathrm{ab}$ & $9.00 \mathrm{ab}$ & 10.68 \\
Control & 2.50 & 35.96 & 64.04 & $0.22 \mathrm{~b}$ & $2.10 \mathrm{~b}$ & 3.25 & 2.67 & 35.03 & 64.97 & $0.30 \mathrm{~b}$ & $2.10 \mathrm{~b}$ & 6.06 \\
$\begin{array}{l}\text { SD } \\
\begin{array}{l}\text { Significance } \\
(5 \%)\end{array}\end{array}$ & 0.46 & 26.06 & $\mathrm{nd}$ & 0.38 & 4.36 & $\mathrm{nd}$ & 0.40 & 28.49 & $\mathrm{nd}$ & 0.41 & 7.66 & $\mathrm{nd}$ \\
\end{tabular}

Values are means of 10 replicates in each soil type. Means followed by the same letter in a column are not significantly different by Turkey Test $(\mathrm{P}=0.05)$. SD: standard deviation from the mean. ns: non-significant. s: significant. nd: not determined. 
In the Alfisol, the inorganic $\mathrm{P}$ sources had $55 \%$ Ndfa, the organic $\mathrm{P}$ source registered $51 \% \mathrm{Ndfa}$, inorganic nitrogen had $38 \%$ Ndfa, seed priming with $\mathrm{P}$ had $40 \%$ and the control treatment had $36 \% \%$ Ndfa (Table 3 ). In the Ultisol, the inorganic P sources had $47 \%$ to $50 \%$ Ndfa while the other treatments registered less than $40 \%$ Ndfa. Obviously, treatments with a higher $\% \mathrm{Ndfa}$ had a lower $\%$ Ndfs. Hence, the control treatment with the lowest \%Ndfa registered the highest \%Ndfs while the inorganic $\mathrm{P}$ sources registered the lowest $\%$ Ndfs in both soil groups (Table 3 ).

The total $\mathrm{N}$ accumulation by the common bean varied significantly $(\mathrm{P}<0.05)$ across the fields between 5 to $20 \mathrm{~kg} \mathrm{ha}^{-1}$ in the Alfisol and between 8 to $26 \mathrm{~kg} \mathrm{ha}^{-1}$ in the Ultisol (Figure 1). In the Alfisol, the organic $\mathrm{P}$ source had a $\mathrm{N}$-total value of $20 \mathrm{~kg} \mathrm{ha}^{-1}$, which was four times larger than the control treatment. In the Ultisol, the $\mathrm{N}$-total was highest for the inorganic $\mathrm{P}+\mathrm{N}\left(26 \mathrm{~kg} \mathrm{ha}^{-1}\right)$ and lowest for the control $\left(8 \mathrm{~kg} \mathrm{ha}^{-1}\right)$ (Figure 1). The share of nitrogen obtained from $\mathrm{N}_{2}$ fixation (N-Ndfa) ranged between 2 to 8 and 2 to $12 \mathrm{~kg} \mathrm{ha}^{-1}$ in the Alfisol and Ultisol, respectively, and the remainder was obtained from the soil (N-Ndfs) (Table 3). Significant differences $(\mathrm{P}<0.05)$ were also observed among the treatments for N-Ndfa (Table 3). In the Alfisol, the organic $\mathrm{P}$ source registered the highest N-Ndfa value of $7.79 \mathrm{~kg} \mathrm{ha}^{-1}$ which was fourfold compared to the control. In the Ultisol, the inorganic $\mathrm{P}+\mathrm{N}$ accumulated 12 $\mathrm{kg} \mathrm{ha}^{-1}$ while the control treatment accumulated $2 \mathrm{~kg} \mathrm{ha}^{-1}$ from nitrogen fixation and the remainder from the soil (N-Ndfs) (Table 3).

The quantity of $\mathrm{P}$ uptake by common bean ranged between 0.30 to $0.35 \mathrm{mg} \mathrm{P} 100$ $\mathrm{mg}^{-1}$ in the Alfisol and between 0.29 to 0.37 mg P $100-\mathrm{mg}^{-1}$ in the Ultisol (Table 2). Inorganic $\mathrm{P}$ treatment obtained higher quantities of $\mathrm{P}$ compared to the other treatments. However, the difference between the treatments was not significant at 5\% significant level (Table 2).

A high standard deviation from the treatment means was noted for the above ground biomass accumulation for common bean, delta-15-N values for maize and common bean, \%Ndfa and $\mathrm{N}-\mathrm{Ndfa}$ for common bean (Table 2 and Table 3 ).

\section{DISCUSION}

The effect of treatment applications on above-ground biomass accumulation was significant probably because of the inherent low levels of $\mathrm{N}$ and $\mathrm{P}$ in the soils of Western Kenya (Vanlauwe et al., 2006). Nitrogen and $\mathrm{P}$ are major nutrient elements required by plants for healthy growth and development (Marschner, 1995). Consequently, any addition of organic or inorganic $\mathrm{N}$ and $\mathrm{P}$ led to
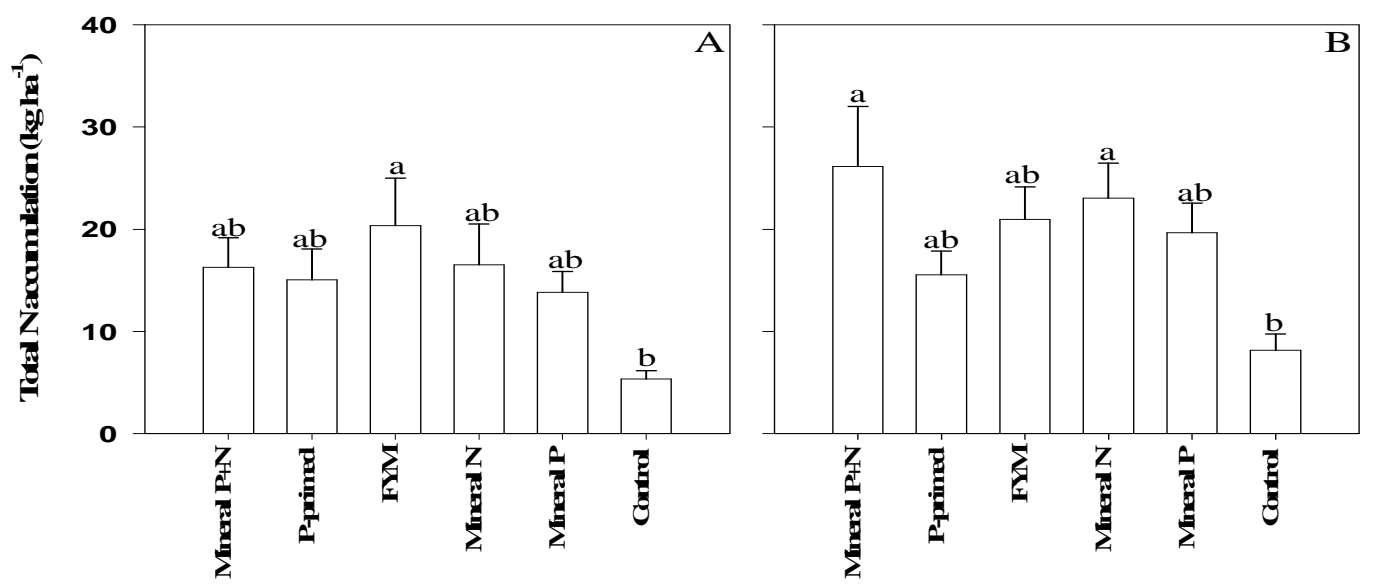

Treatment

Figure 1: Effect of treatments on total nitrogen accumulation by common bean in an Alfisol (A) and an Ultisol (B) in Kakamega, Kenya. Values are means of 10 replicates in each soil type. Bars indicate standard error of the mean. Treatments with the same letter in the same soil group are not significantly different by Turkey Test $(\mathrm{P}=0.05)$. 
a significant increase in the above-ground biomass accumulation of the common bean. The extent to which the common bean accumulated biomass depended on the quality and quantity of available $\mathrm{N}$ and $\mathrm{P}$ nutrients. This could explain why the mineral $\mathrm{P}+\mathrm{N}$ and FYM treatments responded better than the other treatments because these treatments contain both $\mathrm{P}$ and $\mathrm{N}$ nutrient elements. FYM had the best performance in the sandy Alfisol probably because; apart of providing nutrients, the FYM ameliorated the $\mathrm{pH}$, organic carbon level and the water retention capacity of the soil. FYM is known to ameliorate soil physico-chemical properties and enhance crop growth especially in sandy soils. Baijukya et al. (2005) observed an increased in crop yield with the application of $2.5 \mathrm{Mg} \mathrm{ha}^{-1}$ of FYM. However, in Western Kenya, the use of FYM is limited by financial means to buy animals, sufficient land to produce forage and labor for field application of FYM (Ngome, 2006). Treatments in the Ultisol accumulated generally more biomass compared to those in the Alfisol, which could be linked to soil-water availability. The Ultisol of Kakamega is clayey with a higher organic carbon content compared to the sandy Alfisol (Ngome, 2006). Hence, the water retention capacity of the Ultisol is higher, which could sustain plant growth during short drought periods. This also explains why the FYM treatment had a good performance in the sandy Alfisol.

The fact that common bean had consistently lower delta-15-N values for all the treatments compared to the corresponding non-fixing reference maize plant depicts that nitrogen was fixed by the common bean in all the treatments. The estimates of \%Ndfa using ${ }^{15}$ NNAM revealed that a considerable amount of $\mathrm{N}$ could be fixed by the common bean in the Alfisol and Ultisol of Kakamega, if conditions for nitrogen fixation are favourable. The observed variation in $\% \mathrm{Ndfa}$ was related mainly to soil chemical properties particularly $\mathrm{P}$ and $\mathrm{N}$ status. Treatments that received organic or inorganic $\mathrm{P}$ had higher $\%$ Ndfa compared to the other treatments and the performance of the common bean in $\%$ Ndfa was better in the Alfisol compared to the Ultisol with lower levels of P. Phosphorus application has been widely reported to have a significant positive effect on nodulation and nitrogen fixation by legumes as it provides energy in the form of ATP needed for the process (Giller, 2001). Becker et al. (1991) reported an improvement in nodulation performance of Sesbania rostrata with the application of P. Similar observations were made by Ojiem (2006) with common bean in Western Kenya. Conversely, the application of mineral $\mathrm{N}$ apparently reduced $\% \mathrm{Ndfa}$ probably due to a decline in nodulation and nitrogenase enzyme activity. When soil $\mathrm{N}$ level increases through the application of mineral $\mathrm{N}$ fertilizer the nitrogen-fixing legume shifts from symbiotic to mineral $\mathrm{N}$ nutrition. Consequently, the number of nodules reduces, the activity of the nitrogenase enzyme declines and the rate of nitrogen fixation is low (Becker et al., 1991). This is in line with Fujita et al. (1992) who reported a 55\% reduction in nitrogen fixation by groundnut after application of $50 \mathrm{~kg} \mathrm{~N} \mathrm{ha}{ }^{-1}$. This could also explain why the inorganic $\mathrm{N}$ treatment in this experiment had a lower \% Ndfa and a higher \%Ndfs compared to the other treatments. The lower \%Ndfa observed with seed priming compared to organic or inorganic $\mathrm{P}$ sources could be attributed to low concentration of $\mathrm{P}(100 \mathrm{mM})$ in the priming solution. Ajouri et al. (2004) used a $500 \mathrm{mM}$ priming solution to improve crop performance. Hence, a higher concentration of the phosphorus priming solution could be necessary to improve the nitrogen fixing performance of common bean in the Alfisol and the Ultisol of Kakamega. The results obtained for \%Ndfa by common bean in this study were similar to that reported by Ssali and Keya (1986) (43-52\%) in other parts of Kenya using the ${ }^{15} \mathrm{~N}$ dilution $\left({ }^{15} \mathrm{NEM}\right)$. Hence, these results support the fact that the ${ }^{15}$ NNAM is a reliable method for estimating nitrogen fixation by common bean under field conditions.

The results of N-Ndfa and N-Total in this study indicate that common bean can contribute to the $\mathrm{N}$ pool in smallholder farming systems in Kakamega. However, this will depend largely on the farmers' resource endowment, soil and crop management systems. Treatments with a high biomass accumulation were seen to have a larger $\mathrm{N}$ $\mathrm{Ndfa}$ and $\mathrm{N}$-total value which confirms the strong dependency of $\mathrm{N}$ accumulation on biomass production. The total amount of $\mathrm{N}_{2}$ 
fixed or N-Ndfa accumulation is a function of photo assimilation and total dry matter accumulation, and the biomass provides a sink to use the fixed $\mathrm{N}_{2}$ (Giller and Wilson, 1991). This explains why treatments with a higher above-ground biomass accumulated more $\mathrm{N}$ Ndfa and probably why treatments in the Ultisol with higher above-ground biomass also accumulated more N-Ndfa compared to treatments in the Alfisol. Similar results were earlier reported elsewhere (Becker et al., 1991). In Western Kenya smallholder farming systems, the accumulation of biomass by common bean is highly limited by weed infestation and labour for regular weeding is scarce (Nambiro, 2008; Ngome, 2006). Hence, N-Ndfa for common bean in smallholder farming systems in Kakamega could be lower compared to the results obtained in this study. Additionally, the results for $\mathrm{N}-\mathrm{Ndfa}$ and $\mathrm{N}$-total for common bean in this study did not include belowground biomass accumulation, which could explain why the results are lower compared to that reported by Kumarasinghe et al. (1992). These Scientists noted a N-total of $119 \mathrm{~N} \mathrm{ha}^{-1}$ for the climbing bean (Phaseolus vulgaris L.) at 75 days after planting by using the ${ }^{15} \mathrm{~N}$ enrichment method.

The standard deviations from the treatment means observed in most of the tested parameters were high in all the fields probably due to the heterogeneity in biophysical conditions and socio-economic attributes of the smallholder farming systems. Soil type, quality and quantity of farm input use and crop management vary from one farm to another in Kakamega, which could possibly create soil fertility gradients. This is in line with the observations made by Tittonell et al. (2005) and Vanlauwe et al. (2006).

Nitrogen fixation can play an important role in restoring soil fertility in smallholder farming systems in Sub-Saharan Africa. In Western Kenya, the soils are highly exhausted with grave nutrient deficiencies particularly $\mathrm{N}$ and $\mathrm{P}$ (Tittonell et al., 2005). With increasing fuel prices, the cost of mineral fertilizer is rising making it less available to smallholder farmers. Hence, $\mathrm{N}_{2}$ fixation by common bean could be an option to enhance the supply of biologically fixed $\mathrm{N}$ to the depleted maize fields and hence reduce the need for mineral $\mathrm{N}$ fertilizer.

\section{Conclusion}

This study led to quantify the effects of phosphorus sources on nitrogen fixation of field grown common bean in an Alfisol and an Ultisol in Kakamega. The application of inorganic or organic $\mathrm{P}$ improved biomass accumulation and the share of nitrogen from nitrogen fixation. Treatments laid out in the Ultisol accumulated $20 \%$ more biomass compared to the treatments laid out in the Alfisol. The total nitrogen accumulation by the common bean ranged from 5 to $20 \mathrm{~kg} \mathrm{ha}^{-1}$ in the Alfisol and from 8 to $26 \mathrm{~kg} \mathrm{ha}^{-1}$ in the Ultisol. Additionally, treatments with the application of inorganic phosphorus obtained a larger share of the accumulated nitrogen from nitrogen fixation compared to organic $\mathrm{P}$ source, seed priming with $\mathrm{P}$, inorganic $\mathrm{N}$ and the control. The results of this study showed that the addition of inorganic or organic $\mathrm{P}$ sources could differentially improve the $\mathrm{N}_{2}$ fixing capacity of field grown common bean in the Alfisol and the Ultisol of Kakamega, Kenya.

\section{ACKNOWLEDGEMENTS}

I deeply appreciate the financial and material assistance obtained from BIOTA and KAAD. I am grateful also to INRES UniBonn, Germany, KARI-Kakamega, Kenya and IRAD Cameroon for their support.

\section{REFERENCES}

Adjei MB, Quesenbery KH, Chambliss CG. 2002. Nitrogen fixation and inoculation of forage legumes. http://edis.ifas.ufl.edu/ AG152. (Verified on the $4^{\text {th }}$ of May 2006).

Ajouri A, Asgedom H, Becker M. 2004. Seed priming enhances germination and seedling growth of barley under conditions of $\mathrm{P}$ and $\mathrm{Zn}$ deficiency. $J$. Plant Nutri. Soil Sci., 167: 630-636.

Baijukya FP, de Ridder N, Giller KE. 2005. Managing legume cover crops and their residues to enhance productivity of degraded soils in the humid tropics: a case study in Bukoba District, Tanzania. Nutri. Cycl. Agro-ecosyst., 73: 75-78.

Becker M, Diekmann KH, Ladha JK, Dedatta SK, Ottow JCG. 1991. Effect of NPK on growth and nitrogen fixation of Sesbania rostrata as a green manure for lowland 
rice (Oryza sativa L.). Plant Soil., 132: 149-158.

Chikowo R, Mapfumo P, Nyamugafata P, Giller KE. 2004. Maize productivity and mineral $\mathrm{N}$ dynamics following different soil fertility management practices on a depleted sandy soil in Zimbabwe. Agric. Ecosyst. Environ., 102: 119-131.

Fujita K, Ofusu-budu KG, Ogata S. 1992. Biological nitrogen fixation in mixed legume-cereal cropping systems. Plant Soil, 141: 155-175.

Gathumbi SM, Cadisch G, Giller KE. 2002. ${ }^{15} \mathrm{~N}$ natural abundance as a tool for assessing $\mathrm{N}_{2}$-fixation of herbaceous, shrub and tree legumes in improved fallows. Soil Biol. Biochem., 34: 10591071.

Gehring C, Vlek PLG. 2004. Limitations of the N-15 Natural abundance method for estimating biological nitrogen fixation in Amazonian forest legumes. Bas. Appl. Eco., 5: 567-580.

Giller KE. 2001. Nitrogen Fixation in Tropical Cropping Systems. Wallingford $\mathrm{CAB}$ International: Wallingford UK; $\mathrm{p}$. 448.

Giller KE, Cadisch G. 1995. Future benefits from biological nitrogen fixation: ecological approach agriculture. Plant Soil., 174: 255-277.

Giller KE, Wilson KJ. 1991. Nitrogen Fixation in Tropical Cropping Systems. Wallingford CAB International: Wallingford, UK; p. 313.

Harris D, Breese WA, Rao JVDK. 2005. The improvement of crop yield in marginal environments using "on-farm" seed priming: nodulation, nitrogen fixation, and disease resistance. Aust. J. of Agric. Res., 56: 1211-1218.

Hogh-Jensen H, Schjoerring JK, Soussana JF. 2002. The influence of phosphorus deficiency on growth and nitrogen fixation of white clover plants. Annals Bota., 90: 745-753.

Kuang RB, Liao H, Yan XL, Dong YS. 2005. Phosphorus and nitrogen interactions in field-grown soybean as related to genetic attributes of root morphological and nodular traits. J. Int. Plant Biol., 47: 549559.

Kumarasinghe KS, Danso SKA, Zapata F. 1992. Field-evaluation of $\mathrm{N}_{2}$-fixation and
$\mathrm{N}$-partitioning in climbing bean (Phaseolus vulgaris L.) using N-15. Biol. Ferti. Soil., 13: 142-146.

Larnier JE, Jordan DL, Speras FJ, Wells R, Johnson PD. 2005. Peanut response to inoculation and nitrogen fertilizer. Agron. J., 97: 79-84.

Mapfumo P, Mtambanengwe F, Giller KE, Mpepereki S. 2005. Tapping indigenous herbaceous legumes for soil fertility management by resource-poor farmers in Zimbabwe. Agric. Ecosyst. Environ., 109: 221-233.

Marschner H. 1995. Mineral Nutrition of Higher Plants. London Academic Press: London; 889.

Musa AM, Harris D, Johansen C, Kumar J. 2001. Short duration chick-pea to replace fallow after Aman Rice: The role of onfarm seed priming in the high barind track of Bangladesh. Exp. Agric., 37: 509521.

Nambiro E. 2008. Trends in land use and agricultural intensification in Kakamega, Western Kenya. PhD Thesis, Bonn University, Bonn, Germany, p. 132.

Ngome AF. 2006. The contribution of biological nitrogen fixation to $\mathrm{N}$ balances in agricultural production systems of Kakamega District, Kenya. Master thesis, Bonn University, Bonn, Germany, p. 72.

O'Hara GW. 2001. Nutritional constraints on root nodule bacteria affecting symbiotic nitrogen fixation: a review. Aust. J. of Exp. Agric., 41: 417-433.

Ojiem JO. 2006. Exploring socio-ecological niches for legumes in western Kenya smallholder farming systems. PhD thesis, Wageningen University, Wageningen, The Netherlands, p. 169.

Shepherd KD, Soule MJ. 1998. Soil fertility management in West Kenya: dynamic simulation of productivity, profitability and sustainability at different resource endowment levels. Agric. Ecosyst. Environ., 71: 131-145.

Ssali H, Keya SO. 1986. The effects of phosphorus and nitrogen fertilizer levels on nodulation, growth and dinitrogen fixation of three bean cultivars. Trop. Agric., 63: 105-109.

Soil Survey Staff. 1992. Keys to Soil Taxonomy by the Soil Survey Staff. SSMS Technical Monograph No.19. United 
States Department of Agriculture, Pocahontas Press Inc: Virginia, USA; 306.

Somado EA, Becker M, Kuehne RF, Sahrawat KL, Vlek PLG. 2003. Combined effects of legumes with rock phosphorus on rice in West Africa. Agron. J., 95: 1172-1178. SPSS. 2005. SPSS, Inc., Chicago, USA.

Tittonell P, Vanlauwe B, Leffelaar PA, Shepherd KD, Giller KE. 2005. Exploring diversity in soil fertility management of smallholder farms in Western Kenya-II. Within-farm variability in resource allocation, nutrient flows and soil fertility status. Agric. Ecosyst. Environ., 110: 166-184.

Vanlauwe B, Tittonell P, Mukalama J. 2006. Within-farm soil fertility gradients affect response of maize to fertilizer application in western Kenya. Nutr. Cycl. Agroecosyst., 76: 171-182.

Wanek W, Arndt SK. 2002. Difference in delta-15-N signatures between nodulated roots of soybean is indicative of the contribution of symbiotic $\mathrm{N}_{2}$ fixation to plant nitrogen. J. Exp. Bota., 53: 11091118. 